Review

\title{
Leaf Senescence by Magnesium Deficiency
}

\section{Keitaro Tanoi $^{\dagger} * *$ and Natsuko I. Kobayashi ${ }^{\dagger}$}

Graduate School of Agricultural and Life Sciences, The University of Tokyo, 1-1-1 Yayoi, Bunkyo-ku, Tokyo 113-8657, Japan; E-Mail: anikoba@mail.ecc.u-tokyo.ac.jp

* Author to whom correspondence should be addressed; E-Mail: uktanoi@ mail.ecc.u-tokyo.ac.jp; Tel.: +81-3-5841-8496; Fax: +81-3-5841-8193.

$\dagger$ These authors contributed equally to this work.

Academic Editor: Salma Balazadeh

Received: 4 August 2015 / Accepted: 2 December 2015 / Published: 11 December 2015

\begin{abstract}
Magnesium ions $\left(\mathrm{Mg}^{2+}\right)$ are the second most abundant cations in living plant cells, and they are involved in various functions, including photosynthesis, enzyme catalysis, and nucleic acid synthesis. Low availability of $\mathrm{Mg}^{2+}$ in an agricultural field leads to a decrease in yield, which follows the appearance of $\mathrm{Mg}$-deficient symptoms such as chlorosis, necrotic spots on the leaves, and droop. During the last decade, a variety of physiological and molecular responses to $\mathrm{Mg}^{2+}$ deficiency that potentially link to leaf senescence have been recognized, allowing us to reconsider the mechanisms of $\mathrm{Mg}^{2+}$ deficiency. This review focuses on the current knowledge about the physiological responses to $\mathrm{Mg}^{2+}$ deficiency including a decline in transpiration, accumulation of sugars and starch in source leaves, change in redox states, increased oxidative stress, metabolite alterations, and a decline in photosynthetic activity. In addition, we refer to the molecular responses that are thought to be related to leaf senescence. With these current data, we give an overview of leaf senescence induced by $\mathrm{Mg}$ deficiency.
\end{abstract}

Keywords: leaf senescence; magnesium deficiency; transpiration

\section{Introduction}

Magnesium (Mg) is an essential macro-element for life, and it is usually present in cells as a divalent cation. $\mathrm{Mg}^{2+}$ plays an important role in many metabolic processes such as a cofactor of enzyme activity 
with ATP, a stabilizer for ribosomal structure, and the central atom in chlorophyll [1,2]. For steady metabolic processes, $\mathrm{Mg}$ homeostasis in the plant should be highly controlled. In support of this idea, $\mathrm{Mg}$ concentrations have the lowest variation among leaves of environmental samples [3] and the lowest variance among 18 minerals in Arabidopsis M3 mutants, based on an ionomic analysis [4].

Magnesium is abundant in the environment, with more than 20,000 ppm in the earth's crust, making it the eighth most abundant element. Despite its abundance, $\mathrm{Mg}$ deficiency often occurs in the field because of soil acidity and competition with other cations such as hydrogen $\left(\mathrm{H}^{+}\right)$, potassium $\left(\mathrm{K}^{+}\right)$, calcium $\left(\mathrm{Ca}^{2+}\right)$, and ammonium $\left(\mathrm{NH}_{4}{ }^{+}\right)$in the soil [5-9], especially in very sandy soils, and particularly in the culture of tobacco and potatoes [10]. The symptoms of $\mathrm{Mg}$ deficiency in crops have been pointed out by numerous researchers $[8,9,11,12]$. Under normal conditions, the $\mathrm{Mg}$ content is within the range of $0.15 \%-0.35 \%$ of the dry weight of the vegetative parts [2]. When the Mg content is below this range, symptoms emerge in the leaves. Symptoms tend to occur during the period of grain filling or fruit expansion, which influences the quality and quantity of the agricultural product $[8,11,12]$. Magnesium deficient leaves have yellowish, bronze, orange-yellow, or reddish tissues between the green veins $[8,9,13]$, and sometimes they have brown interveinal necrosis (in rice; Figure 1). In general, mature leaves senesce faster than juvenile leaves when $\mathrm{Mg}$ availability is limited [9].

In the present review, we shall focus on the events that occur during leaf senescence under $\mathrm{Mg}$ deficiency. In addition, we shall mention the plant responses to adapt to the $\mathrm{Mg}$ deficient condition.

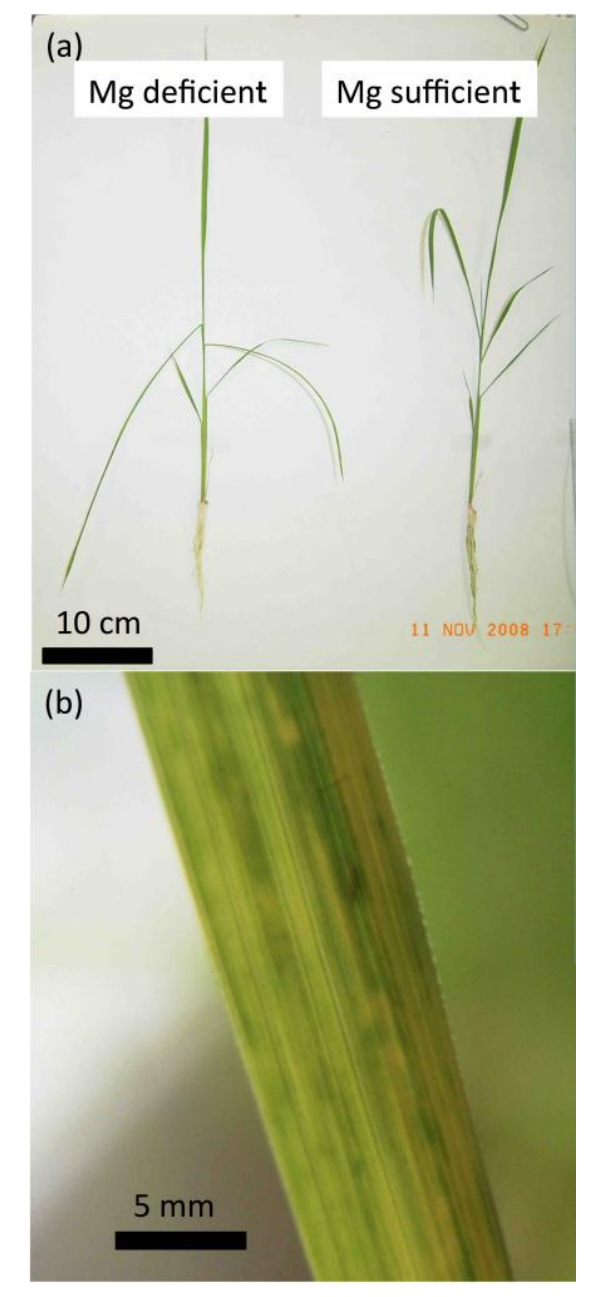

Figure1. Cont. 


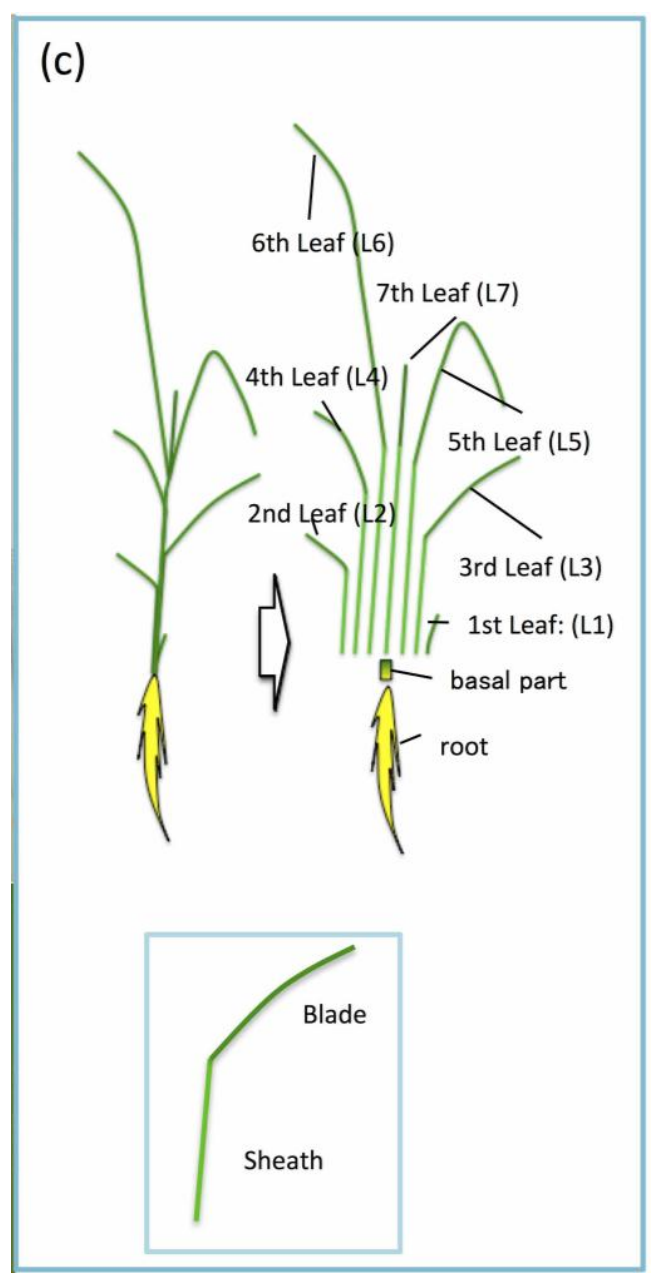

Figure 1. Typical symptoms of magnesium $(\mathrm{Mg})$ deficiency in rice. (a) A rice plant cultured under Mg-deficient or Mg-sufficient conditions. The young mature leaves drooped under $\mathrm{Mg}$ deficiency. (b) Chlorosis of the leaf blade caused by Mg deficiency. (c) Schematic diagram of rice organs before tiller emergence. Leaf positions are numbered from oldest (L1) to newest (L7). Each leaf is composed of a leaf blade and leaf sheath except for L1.

\section{Alterations to Mg Distribution and the Potential Strategies to Recycle Mg during Deficiency}

Experiments with hydroponic cultures have clarified the trends of $\mathrm{Mg}$ concentrations in roots and shoots. In the juvenile phase, the $\mathrm{Mg}$ concentration in the roots decreased within a couple of days after removing Mg from the solution, which was much faster than that in the shoots (e.g., in sugar beet [14], in Arabidopsis [15], and in rice [16]), indicating that $\mathrm{Mg}$ transport from root to shoot is not immediately downregulated by omitting $\mathrm{Mg}$ from the solution. Magnesium occurred at higher concentrations in the shoots than in the roots when Mg availability was sufficient (e.g., in sugar beet [17], in Arabidopsis [15], in rice [16,18], and in castor oil plant [19]), indicating a higher demand of Mg in the shoot. AtMHX, an $\mathrm{Mg}^{2+} / \mathrm{H}^{+}$antiporter, localizes in the vacuolar membrane of xylem parenchyma cells [20] that engage in xylem loading in the roots and xylem unloading at sink organs [21]. Although information about AtMHX has been steadily provided, such as the regulation of expression by upstream open reading frames at translation levels [22], and the physiological characteristics of plants that overexpress the transporter [23], its function in long-distance transport remains unclear. 
$\mathrm{Mg}$ is a mobile ion in addition to nitrogen $(\mathrm{N})$, phosphorus $(\mathrm{P})$, and potassium $(\mathrm{K})$ [24], and thus it is found at high concentrations (several $\mathrm{mM}$ ) in the phloem $[19,25]$. This knowledge supports the observation that newer organs in the shoots have similar or higher $\mathrm{Mg}$ concentrations than older organs under Mg-limited conditions. However, when the differences in $\mathrm{Mg}$ concentrations between $\mathrm{Mg}$-sufficient and -deficient plants were concerned, the bigger gap was found in young mature leaves (L4) rather than in old mature leaves (L2 and L3) of rice (Figure 2); similar trends were observed in sugar beet [17] and Arabidopsis [26,27]. This demonstrates that $\mathrm{Mg}$ retranslocation from old mature leaves is not as vigorous as that from young mature leaves. In contrast to $\mathrm{Mg}$, translocation of $\mathrm{K}$ to the young sink organs from old mature leaves was reported to be comparable to that from young mature leaves under K-deficient conditions [28]. The reason for the difficulties in $\mathrm{Mg}$ retranslocation from old mature leaves remains unknown. Furthermore, the molecular mechanism of Mg translocation has not been characterized yet. Some Mg transporters have been shown to localize to vascular tissues [29], and thus might be involved in translocation. In the case of P, OsPT6, which is induced by P deficiency, is responsible for the retranslocation of phosphate in rice [30].

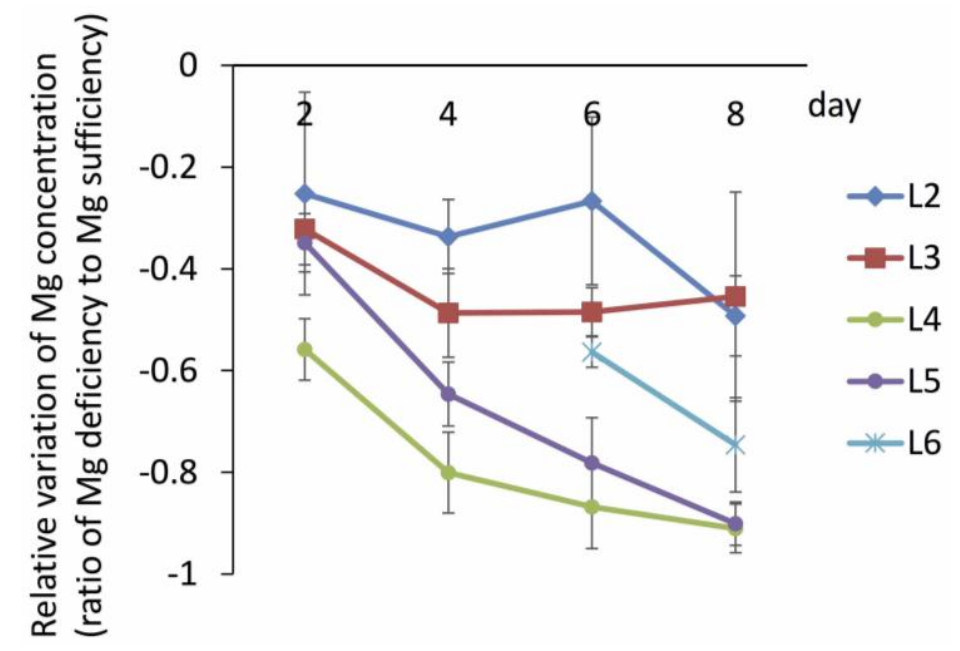

Figure 2. Time course of relative variation of magnesium $(\mathrm{Mg})$ concentrations, modified from the data of Kobayashi et al. (2013) [16]. Values are shown as Mg concentrations in $\mathrm{Mg}$-deficient leaves relative to control leaves. The seedlings of rice were grown hydroponically for two weeks and then transferred to a culture solution without $\mathrm{Mg}$. The leaf positions are defined in Figure 1c.

At the intracellular level, usually $6 \%-25 \%$ of the total $\mathrm{Mg}$ is bound to chlorophyll [2]. This proportion went up to more than $50 \%$ in Mg-deficient poplars grown under low light conditions [2]. This indicates the high requirement for $\mathrm{Mg}$ in chlorophyll and the high activity of $\mathrm{Mg}^{2+}$ transport into chloroplasts. The Mg transporters localized in the chloroplasts, AtMRS2-11/MGT10 and OsMRS2-6, are relatively well characterized and demonstrated to mediate $\mathrm{Mg}^{2+}$ transport [29,31-34]. Aside from the $\mathrm{Mg}$ partitioning in chlorophyll under $\mathrm{Mg}$-deficient conditions, degradation of chlorophyll seems to be promoted by $\mathrm{Mg}$ deficiency. This is supported by transcriptomic studies showing the expression of genes related to the chlorophyll degradation processes, such as, non-yellowing 1 (NYE1: an initiator of chlorophyll degradation) in rice, multidrug resistance protein 3 (MRP3: a vacuolar ATP-binding cassette transporter that transports chlorophyll catabolites) in Arabidopsis [35,36], and red chlorophyll catabolite reductase 
(RCCR: a reductase involved in chlorophyll breakdown during senescence [37-39]) in rice (Figure 3). Degradation of chlorophyll might be related to the regulation of a "metabolic pool" in which $\mathrm{Mg}^{2+}$ concentrations are strictly regulated [2]. In addition to the intracellular processes, it is possible that $\mathrm{Mg}^{2+}$ release from chlorophyll is indirectly related to retranslocation. In the case of $\mathrm{P}$, phosphatase activity was elevated by $\mathrm{P}$ deficiency or senescence, thereby changing the organic $\mathrm{P}$ in mature leaves to more mobile chemical forms, like inorganic $\mathrm{P}$, which was then retranslocated to sink organs [40-42].

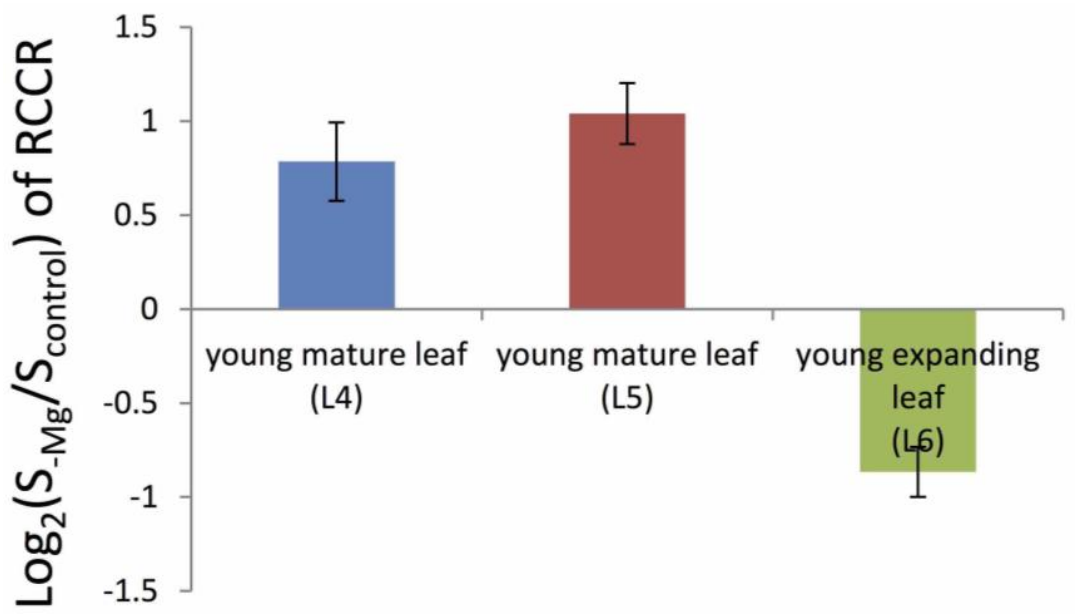

Figure 3. Alteration of red chlorophyll catabolite reductase (RCCR) expression in rice leaves under magnesium ( $\mathrm{Mg}$ )-deficient conditions analyzed using microarray. Each leaf was sampled on Day 6 of an Mg-deficient treatment, after two weeks of pre-culture in the control solution. The leaf positions are defined in Figure 1c.

\section{Initial Physiological Responses to Mg Deficiency}

\subsection{Young Mature Leaves are the Initial Sites of Mg-Deficiency Symptoms}

Monocots are useful for observing every leaf position both separately and in detail. In rice, new leaves emerge about every two days, which makes it possible to determine the leaf maturing stage. Kobayashi et al. (2013) [16] performed an experiment whereby, for each nutrient element, a mineral deficiency was applied for nine days followed by mineral resupply (Figure 4). At Day 12, older leaves (L3 and L4) were dead in the $\mathrm{P}$ and $\mathrm{K}$ treatments, the newest leaf was dead and shoot growth had stopped in the $\mathrm{Ca}$ treatment (L6). At Day 12 in the Mg treatment, the L5 leaf that had experienced Mg-deficient conditions during the stages of rapid elongation, sink-source transition, and early maturation was dead but the other leaves were alive. Similar patterns of leaf senescence during $\mathrm{Mg}$ deficiency were observed in Arabidopsis and sugar beet $[15,17]$. Because the Mg deficiency status differs between the leaf positions, it is necessary to consider an experiment after identifying which leaf is the site of $\mathrm{Mg}$ deficiency before analyzing the mechanism of leaf senescence by $\mathrm{Mg}$ deficiency. 


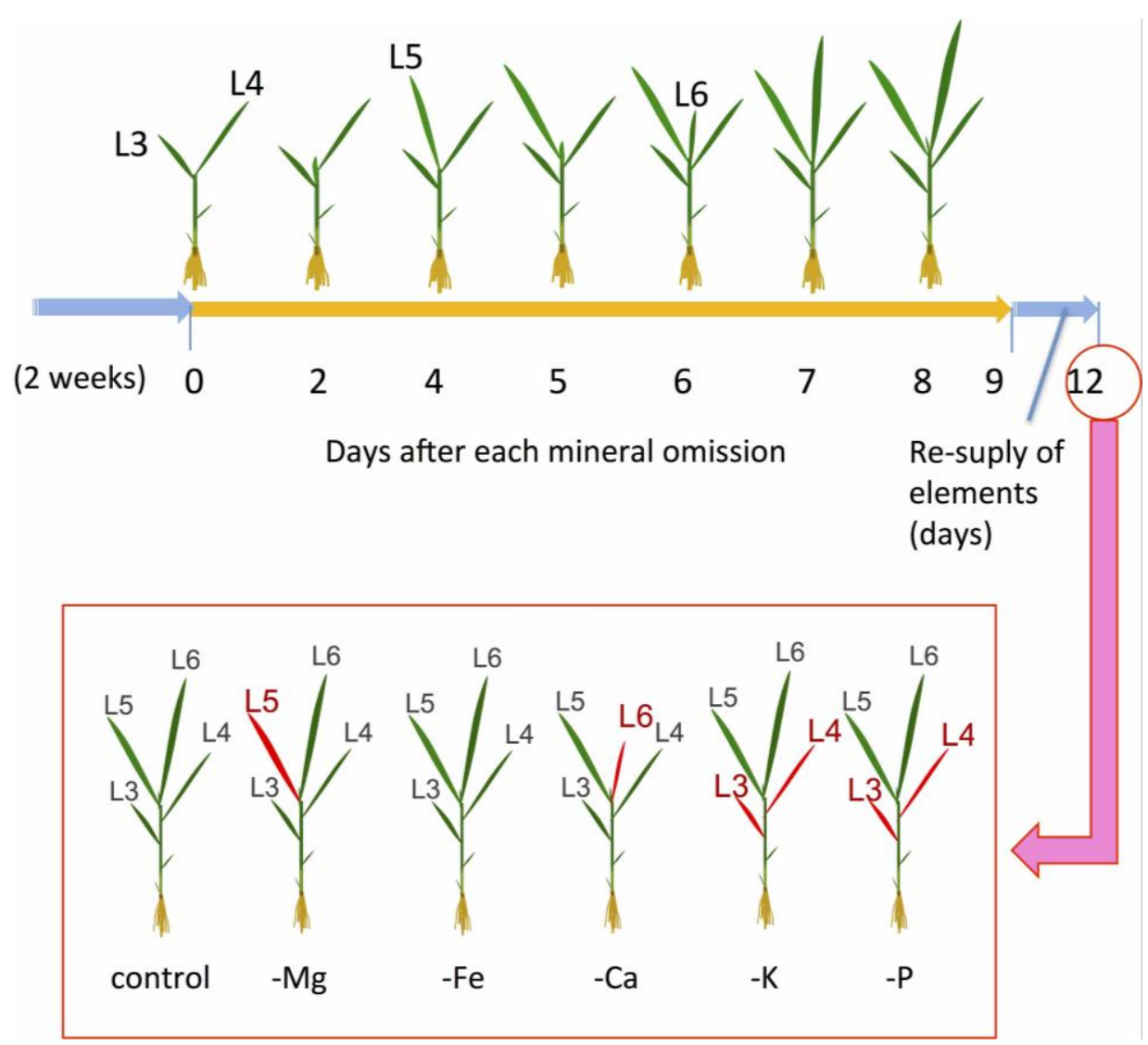

Figure 4. Experimental design for magnesium $(\mathrm{Mg})$, iron $(\mathrm{Fe})$, calcium $(\mathrm{Ca})$, potassium $(\mathrm{K})$, and phosphate $(\mathrm{P})$ deficiency in rice. Seedlings were grown hydroponically for two weeks. The plants were transferred to culture solutions with the target mineral omitted and were grown for nine days. At Day 9, the plants were resupplied with each mineral. The plants were observed at Day 12. The red-colored leaf position indicates a dead leaf. The leaf positions are defined in Figure 1c.

\subsection{The Decline in Transpiration}

The new mechanism of leaf senescence caused by $\mathrm{Mg}$ deficiency has been recently found. In rice, the leaf position L5 that began to emerge just after Mg deficiency started is the site of Mg deficiency, and it was the first leaf to senesce among all leaf positions (Figure 4). Several days before the photosynthetic rate declined in the sensitive leaf position, leaf transpiration rate decreased, which was measured by a portable photosynthesis system (LI-6400, LI-COR, Lincoln, NE, USA) with an attached leaf chamber [16]. Then, minerals in the xylem, including not only $\mathrm{Mg}^{2+}$ but also other solutes, were not supplied from the roots to the leaf [16]. Because the L5 had already expanded and become a source leaf, there was no influx flow via phloem to the leaf. Accordingly, the L5 leaf lost infrastructure for supply of water and minerals. Furthermore, it is hypothesized that the phloem flow from L5 is primarily stopped due to the lack of water supply, which might be the additional cause of the dysfunction of phloem loading frequently observed under the Mg deficiency (see Section 3.3). The symptom of decline in transpiration by $\mathrm{Mg}$ deficiency was also reported in citrus [43] and maize [44]. In addition, the resupply of $\mathrm{Mg}$ to $\mathrm{Mg}$-deficient plants resulted in the recovery of transpiration [44]. 
The importance of the decline in transpiration was supported by the morphological change in $\mathrm{Mg}$ deficiency. The matured leaves were unable to stand up, instead they bent at the leaf collar and the blade shrank, indicating the loss of osmotic pressure of both the cells localized at the leaf collar, and the bulliform cells at the leaf blade [45], respectively. It is possible that the $\mathrm{Mg}$ concentration around the tissues might be too low for the cofactor of $\mathrm{H}^{+}$-ATPase to regulate the membrane potential, which can lead to dysfunction of holding appropriate osmotic pressure of the cells.

It is also possible that the decline in transpiration is directly related to drought stress. Preliminary results suggest that in rice, the transcription levels of OsMYB4, a transcription factor involved in cold acclimation and drought tolerance [46], and some of the OsDREBs, transcription factors involved in drought, high salt, and cold stress [47], were induced by $\mathrm{Mg}$-deficient leaves. Further experiments are needed to clarify the mechanisms involved.

\subsection{Sugar and Starch Accumulation}

Photosynthates and starches accumulate in young mature leaves before any decline in biomass or photosynthetic activities in common bean [48-50], sugar beet [14,17], and Arabidopsis [15]. Potassium deficiency induces soluble sugar accumulation in the leaves but without starch accumulation in common bean [49], Arabidopsis [51], sugar beet [36], rice [16,18,52], and citrus [53].

Sucrose accumulation in source leaves was explained by the defect of phloem loading of sucrose [50]. Phloem dysfunction was suggested to be caused by the mechanism whereby the lack of $\mathrm{Mg}$ reduces the activity of $\mathrm{H}^{+}$-ATPase localized at sieve tube membranes, leading to the depolarization of the membrane potential, and the decline in phloem loading of sucrose through sucrose- $\mathrm{H}^{+}$symporters $[36,54]$. The elevated transcript level of the sucrose $/ \mathrm{H}^{+}$transporter gene $B v S U T 1$ might indicate that plants try to cope with the increased sucrose content by $\mathrm{Mg}$ deficiency [17]. When $\mathrm{Mg}$ was resupplied to plants accumulating sucrose by $\mathrm{Mg}$ deficiency, the sucrose level decreased as early as $12 \mathrm{~h}$ afterward [50], clearly demonstrating the importance of $\mathrm{Mg}$ on phloem loading of sucrose.

Starch accumulation in chloroplast at source leaves is one of the typical symptoms of $\mathrm{Mg}$ deficiency. The key enzymes of starch synthesis such as ADP-glucose pyrophosphorylase [55,56] and phosphoglucomutase [57] localize in chloroplast and demand $\mathrm{Mg}^{2+}$ as a cofactor. It indicates that the $\mathrm{Mg}$ concentration in chloroplasts remains adequate even though the cells around sieve elements are struggling with low $\mathrm{Mg}$ condition and the phloem loading of sucrose looses its function. Verbruggen and Hermans (2013) [36] also discussed that the potential prime targets of $\mathrm{Mg}$ depletion are the sieve elements and companion cells rather than the chloroplasts of mesophyll parenchyma. Nevertheless, the regulation system of starch biosynthesis in source leaves remains unclear even under $\mathrm{Mg}$ sufficient conditions [56]. There have been reports showing the relationship between sucrose synthases (SuSy) and starch accumulation in tomato stems [58] whereby SuSy controlled the starch biosynthesis process in potato source leaves $[59,60]$. On the other hand, SuSy was not essential for normal growth or normal amounts of leaf starch synthesis in Arabidopsis [61]. The mechanism of starch accumulation induced by $\mathrm{Mg}$ deficiency is far from being understood.

The accumulation of carbohydrates in source leaves induced by $\mathrm{Mg}$ deficiency causes alterations in photosynthetic carbon metabolism and restricts $\mathrm{CO}_{2}$ fixation, probably leading to the generation of reactive oxygen species (ROS) through leakage of electrons and absorbed energy from photosynthesis [62]. 
Indeed, the starch-accumulating site visualized by iodine staining seemed to coincide with the area of chlorotic symptoms in Arabidopsis [15], sugar beet [17], and rice [16].

\subsection{The Influence on the Photosynthetic Apparatus by Mg-Deficiency Associated with Chlorophyll}

After sugars and starches begin to accumulate, a decline in photosynthetic activity appears. Recently, the events relating to a decline in photosynthesis by $\mathrm{Mg}$ deficiency were described well in sugar beet [14] and in Sulla carnosa [63]. In sugar beet, the photosystems (PS) II and I were downregulated by $\mathrm{Mg}$ deficiency, although with contrasting responses. The light absorption processes relating to antenna complexes containing $\mathrm{Chl} b$ were reduced in PSII. On the other hand, the amount of core complexes were reduced in PSI [14]. In Sulla carnosa, low Mg condition caused negative effects on the abundance of PSI-related polypeptides, and consequently PSI photochemistry and capacity for cyclic electron transport, showing the main target of Mg deficiency is PSI rather than PSII [63]. In addition, a proteomic analysis using matrix-assisted laser desorption/ionization time-of-flight tandem mass spectrometry on $\mathrm{Mg}$-deficient citrus demonstrated the decrease of many proteins involved in photosynthesis [43]. The subsequent influence on chlorophyll synthesis and chlorophyll $a / b$ ratio was well documented in the review by Verbruggen and Hermans (2013) [36].

\section{The Mechanism of Chlorosis and Necrosis of Leaves Induced by Mg Deficiency}

The candidates causing chlorosis and necrosis by $\mathrm{Mg}$ deficiency were reported to be photosynthate accumulation, ROS, redox change, abscisic acid (ABA) signaling, ethylene response, and metal accumulation. In general, the combination of ROS and antioxidative defenses is associated with any kind of stress reaction, including Mg deficiency. Cakmak and Kirkby (2008) [62] found that the accumulation of carbohydrates and the impairment in photosynthetic $\mathrm{CO}_{2}$ fixation in $\mathrm{Mg}$-deficient leaves appears to proceed to ROS generation. Peng et al. (2015) [43] reported that enhancing the levels of proteins involved in ROS scavenging, such as superoxide dismutase (SOD), was found both in the roots and leaves of citrus under Mg deficiency. Anthocyanins, which could be involved in photoprotection as an antioxidant [64], accumulated in the source leaves during Mg-deficiency in rice, suggesting ROS-mediated leaf senescence [16]. Mg-deficiency induced ROS scavengers such as reduced ascorbic acid and SH-containing compounds [62,65], as well as the activities of SOD [65,66], ascorbate peroxidase [65], glutathione reductase [65,66], and catalase [65]. In addition, $\mathrm{Mg}$ deficiency changed the redox balance to more reduced forms of ascorbate [35] and glutathione [35,65,66], suggesting that the protection against oxidative stresses was caused by $\mathrm{Mg}$ deficiency.

$\mathrm{Mg}$ deficiency influences plant hormone levels and signaling. Ethylene, a plant hormone responsible for fruit ripening, leaf senescence, and stress response signaling, was reported to be increased by $\mathrm{Mg}$ deficiency [35]. Also, the genes encoding ethylene biosynthetic enzymes were enhanced in Arabidopsis [35], and in rice (our recent data). Interestingly, ethylene production was increased under mild drying in tomato leaves [67,68]. Furthermore, ABA signaling might be one of the main targets of $\mathrm{Mg}$ deficiency. Hermans et al. (2010) [26] showed that half of the upregulated genes in leaves with short-term Mg-deficiency were also ABA-responsive in Arabidopsis. Interestingly, the central oscillator of the circadian clock in roots was also influenced by short-term Mg-deficiency [26], which might be involved in a part of ABA and ethylene signaling that is dependent on the circadian clock or circadian rhythm [36]. 
$\mathrm{ABA}$ and metabolites related to water stress such as citrate and myo-inositol were influenced by $\mathrm{Mg}$ deficiency in rice [16]. Citrate accumulation occurred with drought and salinity stress [69-72] as well as with ABA treatment [73]. Myo-inositol derivatives were present as lipids and water-soluble compounds, and their metabolism is related to water stress [74]. The concentration of myo-inositol in sensitive leaf positions of rice decreased by $50 \%$ from that of the control during $\mathrm{Mg}$ deficiency, and it did not show any decline during $\mathrm{K}$, iron $(\mathrm{Fe}), \mathrm{Ca}$, and $\mathrm{P}$ deficiency [16]. The large decreasing rate, 50\%, implied an important role for myo-inositol signaling in response to $\mathrm{Mg}$ deficiency. Interestingly, the influences on myo-inositol concentration and citrate were found before any symptoms emerged, except for the decline in transpiration in rice leaves sensitive to low $\mathrm{Mg}$ [16].

By employing a multi-element analysis technique, the ion balance under $\mathrm{Mg}$ deficiency was examined in Arabidopsis [27,35] and in rice (Figure 5). In Arabidopsis, the concentrations of Ca, Fe, and zinc (Zn) in young mature leaves were increased by Mg deficiency [35], which was similar to the effects observed in rice. Similarly, the concentrations of manganese in young leaves were tripled by $\mathrm{Mg}$ deficiency in mulberry [75]. It is possible that the imbalance of minerals causes ROS production [35].

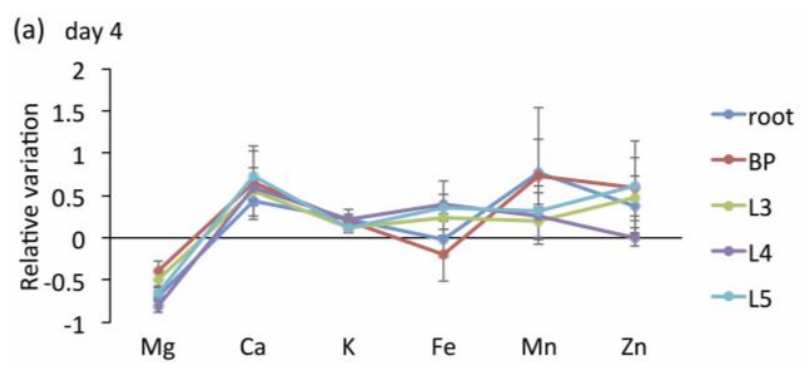

(c) $\mathrm{Mn}$
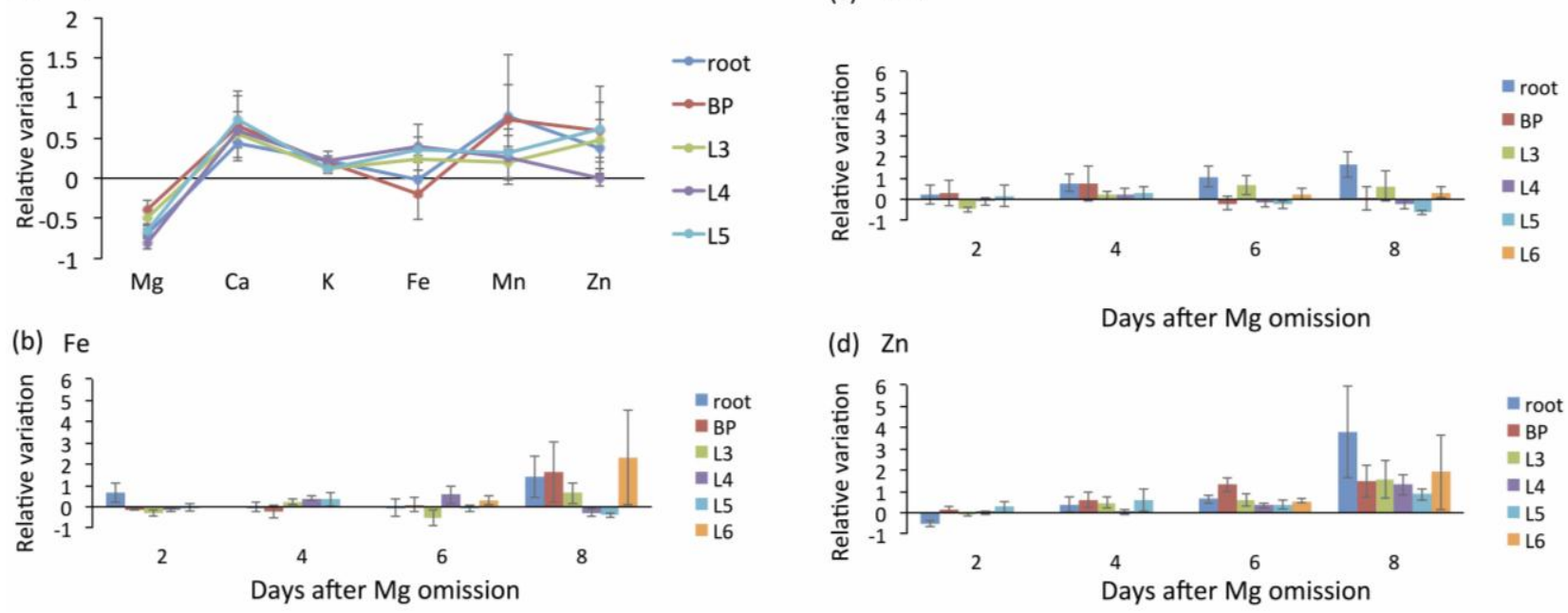

Figure 5. Relative variations of minerals. (a) The relative mineral concentrations under magnesium (Mg) deficiency at Day 4. The leaf positions (L3, L4, L5, and L6) and other organs (root and basal part (BP)) are defined in Figure 1c. (b) Time course of relative iron (Fe) concentrations in Mg-deficient plants. (c) Time course of relative manganese (Mn) concentrations in Mg-deficient plants. (d) Time course of relative zinc ( $\mathrm{Zn}$ ) concentrations in Mg-deficient plants.

\section{Responses of Mg Transporters to Mg Deficiency}

The activities of transport or translocation systems are dependent on the availability of most essential minerals (e.g., phosphate [76], nitrate [77], ammonium [78], potassium [79], sulfate [80], iron [81,82], manganese [83], zinc [82,84] and boron [85]). In the bacterium Salmonella, expression of the transport systems MgtA and MgtB are transcriptionally induced by low Mg conditions [86] and are regulated by the $\mathrm{Mg}^{2+}$-regulated PhoP-PhoQ two-component system [87-89]. Recently, Mao et al. (2014) [90] reported that the gene MGT6/MRS2-4 was induced by Mg deficiency as early as $12 \mathrm{~h}$ afterward and that 
it contributed to $\mathrm{Mg}$ uptake under low Mg conditions. In contrast, gene expression of the MRS2 family of transporters was reported to have no response to short- or long-term Mg-deficiency by transcriptomic studies [26,35], and most of the homologous genes of rice were downregulated by Mg deficiency (Figure 6). Further study is needed to clarify this contradiction. Regarding the physiological responses, $\mathrm{Mg}$ uptake activity assayed using ${ }^{28} \mathrm{Mg}^{2+}$ was elevated under $\mathrm{Mg}$ deficiency in rice, which was drastically reduced almost to the control level or slightly more within $5 \mathrm{~min}$ after $\mathrm{Mg}$ resupply. The similar mechanism of the structure modification at the gating site for cytoplasmic $\mathrm{Mg} 2+$ reported in $\mathrm{MgtE}$ [91] and CorA [92,93] might be involved in the rapid response in plant roots.

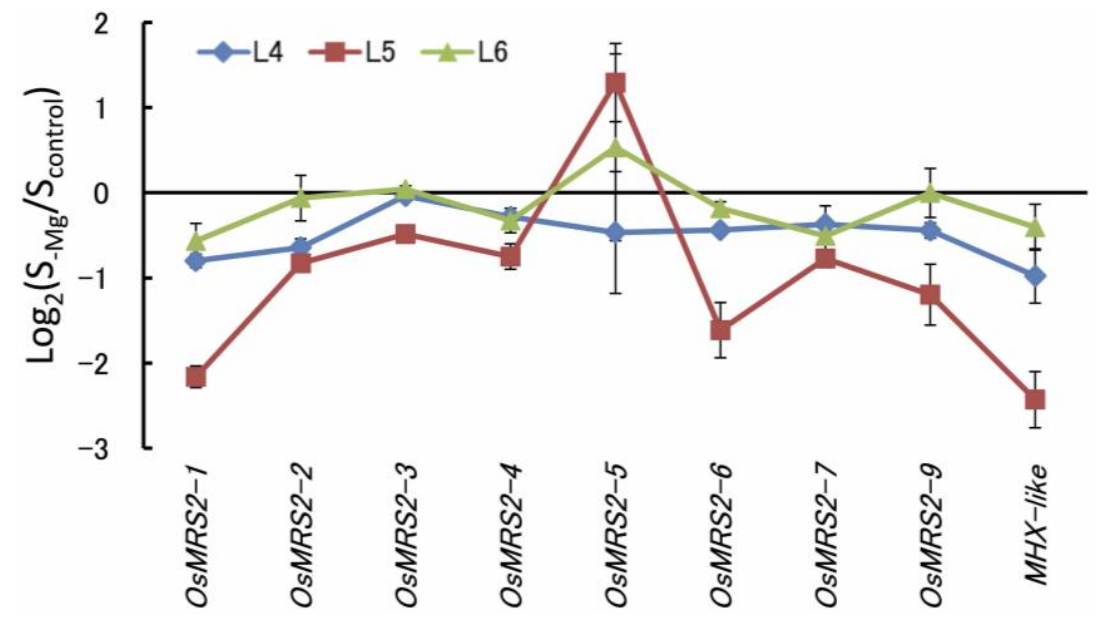

Figure 6. Relative expression of magnesium $(\mathrm{Mg})$ transporters in each rice leaf position. Each leaf was collected and analyzed at Day 6 of the Mg-deficient condition following two weeks of culture with the control solution. The leaf positions (L4, L5, L6) are defined in Figure 1c.

\section{Summary and Perspective}

After many years of research examining the mechanism of $\mathrm{Mg}$ deficiency, the overall hierarchy of plant responses to $\mathrm{Mg}$ deficiency has been clarified (Figure 7). However, the studies that reveal the regulatory network of the senescence symptoms of $\mathrm{Mg}$ deficiency have been just started. In particular, the involvement of $\mathrm{ABA}$ and ethylene signaling in the regulatory network are of interest for further studies. A combination of omics approaches, such as transcriptomics [26,35], proteomics [43,94], and ionomics [27], would be useful for clarifying the molecular regulatory system. Surprisingly, there is only a single report employing forward genetics to examine $\mathrm{Mg}$ deficiency [95]. Definitive evidence is expected to be provided by mutants obtained using forward genetics as well as reverse genetics in future investigations.

Plants have diverse responses to $\mathrm{Mg}$ deficiency, most of which are related to coping with the problems occurring upon $\mathrm{Mg}$ absence, such as chlorophyll degradation and antioxidation. In addition, the fact that there are various levels of tolerance to $\mathrm{Mg}$ deficiency among plants makes us realize that veiled mechanisms of $\mathrm{Mg}$ tolerance must exist in the plant kingdom. In this context, it is worth noting the importance of dealing with plants tolerant to $\mathrm{Mg}$ shortage. To resolve the $\mathrm{Mg}$-deficiency problem in the agricultural field, we require more knowledge about the mechanisms of plant senescence caused by conditions of low $\mathrm{Mg}$. 


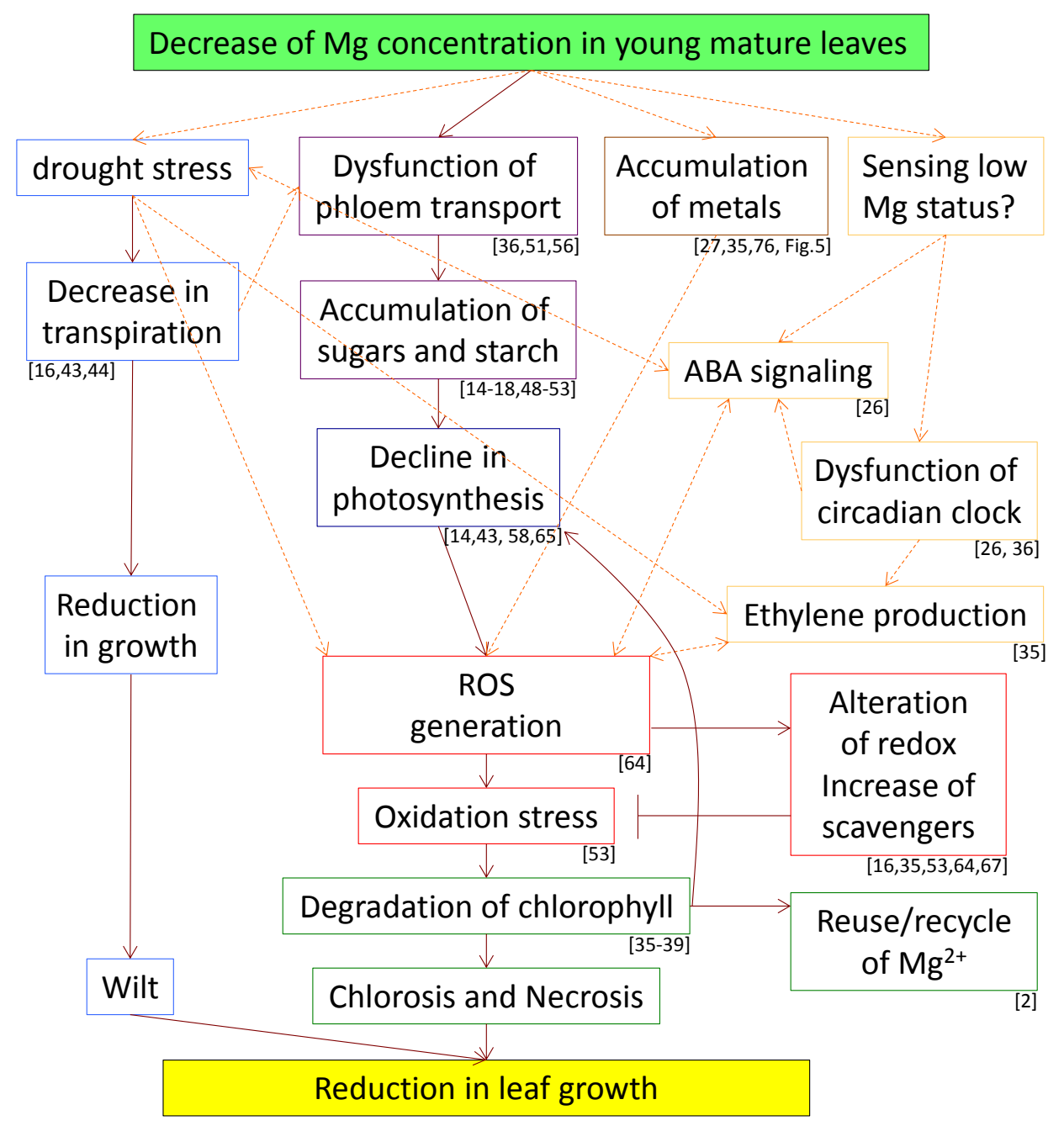

Figure 7. Schematic summary of events and their interrelationships in young mature leaves under magnesium $(\mathrm{Mg})$ deficient conditions. The colors of frame borders shows categories; light blue: drought stress, purple: accumulation of photosynthates, brown: accumulation of metals, yellow: hypothetic signaling, blue: photosynthesis, red: oxidation stress, green: chlorophyll. The orange dotted lines indicate the hypotheses shown by recent studies and the present review. ABA, abscisic acid; ROS, reactive oxygen species.

\section{Acknowledgments}

We thank N. Aoki for discussions on starch synthesis.

\section{Author Contributions}

K.T. prepared the figures; K.T and N.I.K wrote the manuscript. All authors discussed, edited and approved the final version.

\section{Conflicts of Interest}

The authors declare no conflict of interest. 


\section{References}

1. Buchanan, B.B. Role of light in the regulation of chloroplast enzymes. Annu. Rev. Plant Physiol. 1980, 31, 341-374.

2. Marschner, H. Mineral Nutrition in Higher Plants; 2nd ed.; Academic Press: London, UK, 1995.

3. Takata, J.; Takamatsu, T.; Satake, K.; Sase, H. Data on Elemental Concentration in Land Plants by Neutron Activation Analysis (No.1); Takata, J., Takamatsu, T., Satake, K., Sase, H., Eds.; National Institute for Environmental Studies: Tsukuba, Japan, 1994

4. Lahner, B.; Gong, J.; Mahmoudian, M.; Smith, E.L.; Abid, K.B.; Rogers, E.E.; Guerinot, M.L.; Harper, J.F.; Ward, J.M.; McIntyre, L.; et al. Genomic scale profiling of nutrient and trace elements in Arabidopsis thaliana. Nat. Biotechnol. 2003, 21, 1215-1221.

5. Kobayashi, N.I.; Iwata, N.; Saito, T.; Suzuki, H.; Iwata, R.; Tanoi, K.; Nakanishi, T.M. Application of ${ }^{28} \mathrm{Mg}$ for characterization of $\mathrm{Mg}$ uptake in rice seedling under different $\mathrm{pH}$ conditions. J. Radioanal. Nucl. Chem. 2013, 296, 531-534.

6. Jacoby, B. Calcium-magnesium ratios in the root medium as related to magnesium uptake by citrus seedlings. Plant Soil 1961, 15, 74-80.

7. Tanaka, H.; Ougimoto, T.; Sahashi, H. Effects of calcium and magnesium of nutrient solution on their composition in leaves of tomato seedlings. Jpn. J. Soil Sci. Plant Nutr. 1991, 62, 507-511.

8. Bennett, W.F. Nutrient Deficiencies and Toxicities in Crop Plants; Bennett, W.F., Ed.; APS Press: St. Paul, MN, USA, 1993.

9. Uchida, R. Essential Nutrients for Plant Growth: Nutrient Functions and Deficiency Symptoms; Silva, J.A., Uchida, R., Eds.; College of Tropical Agriculture and Human Resources, University of Hawaii at Manoa: Hawaii, HI, USA, 2000.

10. Teuscher, H.; Adler, R. The Soil and Its Fertility; Teuscher, H., Adler, R., Eds.; Reinhold Publishing Corporation: New York, NY, USA, 1960.

11. Aitken, R.L.; Dickson, T.; Hailes, K.J.; Moody, P.W. Response of field-grown maize to applied magnesium in acidic soils in north-eastern Australia. Aust. J. Agr. Res. 1999, 50, 191-198.

12. Moss, G.I.; Higgins, M.L. Magnesium influences on the fruit quality of sweet orange (Citrus sinensis L. osbeck). Plant Soil 1974, 41, 103-112.

13. Hariadi, Y.; Shabala, S. Screening broad beans (Vicia faba) for magnesium deficiency. I. Growth characteristics, visual deficiency symptoms and plant nutritional status. Funct. Plant Biol. 2004, 31, 529-537.

14. Hermans, C.; Johnson, G.N.; Strasser, R.J.; Verbruggen, N. Physiological characterisation of magnesium deficiency in sugar beet: Acclimation to low magnesium differentially affects photosystems I and II. Planta 2004, 220, 344-355.

15. Hermans, C.; Verbruggen, N. Physiological characterization of Mg deficiency in Arabidopsis thaliana. J. Exp. Bot. 2005, 56, 2153-2161.

16. Kobayashi, N.I.; Saito, T.; Iwata, N.; Ohmae, Y.; Iwata, R.; Tanoi, K.; Nakanishi, T.M. Leaf senescence in rice due to magnesium deficiency mediated defect in transpiration rate before sugar accumulation and chlorosis. Physiol. Plant 2013, 148, 490-501. 
17. Hermans, C.C.; Bourgis, F.F.; Faucher, M.M.; Strasser, R.J.R.; Delrot, S.S.; Verbruggen, N.N. Magnesium deficiency in sugar beets alters sugar partitioning and phloem loading in young mature leaves. Planta 2005, 220, 541-549.

18. Ding, Y.; Luo, W.; Xu, G. Characterisation of magnesium nutrition and interaction of magnesium and potassium in rice. Ann. Appl. Biol. 2006, 149, 111-123.

19. Zhong, W.; Schobert, C.; Komor, E. Transport of magnesium ions in the phloem of Ricinus communis L. seedlings. Planta 1993, 190, 114-119.

20. Shaul, O.; Hilgemann, D.W.; de-Almeida-Engler, J.; van Montagu, M.; Inz, D.; Galili, G. Cloning and characterization of a novel $\mathrm{Mg}^{2+} / \mathrm{H}^{+}$exchanger. EMBO J. 1999, 18, 3973-3980.

21. Shaul, O. Magnesium transport and function in plants: The tip of the iceberg. Biometals 2002, 15, 309-323.

22. David-Assael, O.; Saul, H.; Saul, V.; Mizrachy-Dagri, T.; Berezin, I.; Brook, E.; Shaul, O. Expression of AtMHX, an Arabidopsis vacuolar metal transporter, is repressed by the $5^{\prime}$ untranslated region of its gene. J. Exp. Bot. 2005, 56, 1039-1047.

23. Berezin, I.; Mizrachy-Dagry, T.; Brook, E.; Mizrahi, K.; Elazar, M.; Zhuo, S.; Saul-Tcherkas, V.; Shaul, O. Overexpression of AtMHX in tobacco causes increased sensitivity to $\mathrm{Mg}^{2+}, \mathrm{Zn}^{2+}$, and $\mathrm{Cd}^{2+}$ ions, induction of V-ATPase expression, and a reduction in plant size. Plant Cell Rep. 2008, 27, 939-949.

24. Thimann, K.V. Senescence in Plants; Thimann, K.V., Ed.; CRC Press, Inc: Florida, FL, USA, 1986.

25. Hayashi, H.; Chino, M. Collection of pure phloem sap from wheat and its chemical composition. Plant Cell Physiol. 1986, 27, 1387-1393.

26. Hermans, C.; Vuylsteke, M.; Coppens, F.; Craciun, A.; Inzé, D.; Verbruggen, N. Early transcriptomic changes induced by magnesium deficiency in Arabidopsis thaliana reveal the alteration of circadian clock gene expression in roots and the triggering of abscisic acid-responsive genes. New Phytol. 2010, 187, 119-131.

27. Hermans, C.; Conn, S.J.; Chen, J.; Xiao, Q.; Verbruggen, N. An update on magnesium homeostasis mechanisms in plants. Metallomics 2013, 5, 1170-1183.

28. Nobori, T.; Kobayashi, N.I.; Tanoi, K.; Nakanishi, T.M. Effects of potassium in reducing the radiocesium translocation to grain in rice. Soil Sci. Plant Nutr. 2014, 60, 772-781.

29. Gebert, M.; Meschenmoser, K.; Svidovà, S.; Weghuber, J.; Schweyen, R.; Eifler, K.; Lenz, H.; Weyand, K.; Knoop, V. A root-expressed magnesium transporter of the MRS2/MGT gene family in Arabidopsis thaliana allows for growth in low-Mg ${ }^{2+}$ environments. Plant Cell 2009, 21, 4018-4030.

30. Ai, P.; Sun, S.; Zhao, J.; Fan, X.; Xin, W.; Guo, Q.; Yu, L.; Shen, Q.; Wu, P.; Miller, A.J.; Xu, G. Two rice phosphate transporters, OsPht1;2 and OsPht1;6, have different functions and kinetic properties in uptake and translocation. Plant J. 2009, 57, 798-809.

31. Drummond, R.S.M.; Tutone, A.; Li, Y.-C.; Gardner, R.C. A putative magnesium transporter AtMRS2-11 is localized to the plant chloroplast envelope membrane system. Plant Sci. 2006, 170, $78-89$.

32. Saito, T.; Kobayashi, N.I.; Tanoi, K.; Iwata, N.; Suzuki, H.; Iwata, R.; Nakanishi, T.M. Expression and functional analysis of the CorA-MRS2-ALR-type magnesium transporter family in rice. Plant Cell Physiol. 2013, 54, 1673-1683. 
33. Li, L.; Tutone, A.F.; Drummond, R.S.; Gardner, R.C.; Luan, S. A novel family of magnesium transport genes in Arabidopsis. Plant Cell 2001, 13, 2761-2775.

34. Schock, I.; Gregan, J.; Steinhauser, S.; Schweyen, R.; Brennicke, A.; Knoop, V. A member of a novel Arabidopsis thaliana gene family of candidate $\mathrm{Mg}^{2+}$ ion transporters complements a yeast mitochondrial group II intron-splicing mutant. Plant J. 2000, 24, 489-501.

35. Hermans, C.; Vuylsteke, M.; Coppens, F.; Cristescu, S.M.; Harren, F.J.M.; Inzé, D.; Verbruggen, N. Systems analysis of the responses to long-term magnesium deficiency and restoration in Arabidopsis thaliana. New Phytol. 2010, 187, 132-144.

36. Verbruggen, N.; Hermans, C. Physiological and molecular responses to magnesium nutritional imbalance in plants. Plant Soil 2013, 368, 87-99.

37. Wüthrich, K.L.; Bovet, L.; Hunziker, P.E.; Donnison, I.S.; Hörtensteiner, S. Molecular cloning, functional expression and characterisation of RCC reductase involved in chlorophyll catabolism. Plant J. 2000, 21, 189-198.

38. Hörtensteiner, S. Stay-green regulates chlorophyll and chlorophyll-binding protein degradation during senescence. Trends Plant Sci. 2009, 14, 155-162.

39. Hörtensteiner, S. Update on the biochemistry of chlorophyll breakdown. Plant Mol. Biol. 2013, 82, $505-517$.

40. Duff, S.M.; Plaxton, W.C.; Lefebvre, D.D. Phosphate-starvation response in plant cells: De novo synthesis and degradation of acid phosphatases. Proc. Natl. Acad. Sci. USA 1991, 88, 9538-9542.

41. Jeschke, W.D.; Kirkby, E.A.; Peuke, A.D.; Pate, J.S.; Hartung, W. Effects of P deficiency on assimilation and transport of nitrate and phosphate in intact plants of castor bean (Ricinus communis L.). J. Exp. Bot. 1997, 48, 75-91.

42. Himelblau, E.; Amasino, R.M. Nutrients mobilized from leaves of Arabidopsis thaliana during leaf senescence. J. Plant Physiol. 2001, 158, 1317-1323.

43. Peng, H.-Y.; Qi, Y.-P.; Lee, J.; Yang, L.-T.; Guo, P.; Jiang, H.-X.; Chen, L.-S. Proteomic analysis of Citrus sinensis roots and leaves in response to long-term magnesium-deficiency. BMC Genom. 2015, 16, 87, doi:10.1186/s12864-015-1462-z.

44. Jezek, M.; Geilfus, C.-M.; Bayer, A.; Mühling, K.-H. Photosynthetic capacity, nutrient status, and growth of maize (Zea mays L.) upon $\mathrm{MgSO}_{4}$ leaf-application. Front. Plant Sci. 2014, 5, 781, doi:10.3389/fpls.2014.00781.

45. Jabnoune, M.; Espeout, S.; Mieulet, D.; Fizames, C.; Verdeil, J.-L.; Conéjéro, G.; Rodríguez-Navarro, A.; Sentenac, H.; Guiderdoni, E.; Abdelly, C.; et al. Diversity in expression patterns and functional properties in the rice HKT transporter family. Plant Physiol. 2009, 150, 1955-1971.

46. Pasquali, G.; Biricolti, S.; Locatelli, F.; Baldoni, E.; Mattana, M. Osmyb4 expression improves adaptive responses to drought and cold stress in transgenic apples. Plant Cell Rep. 2008, 27, 1677-1686.

47. Dubouzet, J.G.; Sakuma, Y.; Ito, Y.; Kasuga, M.; Dubouzet, E.G.; Miura, S.; Seki, M.; Shinozaki, K.; Yamaguchi-Shinozaki, K. OsDREB genes in rice, Oryza sativa L., encode transcription activators that function in drought-, high-salt- and cold-responsive gene expression. Plant J. 2003, 33, 751-763.

48. Fischer, E.S.; Bremer, E. Influence of magnesium deficiency on rates of leaf expansion, starch and sucrose accumulation, and net assimilation in Phaseolus vulgaris. Physiol. Plant 1993, 89, 271-276. 
49. Cakmak, I.; Hengeler, C.; Marschner, H. Partitioning of shoot and root dry matter and carbohydrates in bean plants suffering from phosphorus, potassium and magnesium deficiency. J. Exp. Bot. 1994, 45, $1245-1250$.

50. Cakmak, I.; Hengeler, C.; Marschner, H. Changes in phloem export of sucrose in leaves in response to phosphorus, potassium and magnesium deficiency in bean plants. J. Exp. Bot. 1994, 45, 1251-1257.

51. Hermans, C.; Hammond, J.P.; White, P.J.; Verbruggen, N. How do plants respond to nutrient shortage by biomass allocation? Trends Plant Sci. 2006, 11, 610-617.

52. Cai, J.; Chen, L.; Qu, H.; Lian, J.; Liu, W.; Hu, Y.; Xu, G. Alteration of nutrient allocation and transporter genes expression in rice under N, P, K, and Mg deficiencies. Acta Physiol. Plant 2012, 34 , 939-946.

53. Lavon, R.; Goldschmidt, E.E.; Salomon, R.; Frank, A. Effect of potassium, magnesium, and calcium deficiencies on carbohydrate pools and metabolism in Citrus Leaves. J. Am. Soc. Hortic. Sci. 1995, 120, $54-58$.

54. Marschner, H.; Kirkby, E.A.; Cakmak, I. Effect of mineral nutritional status on shoot-root partitioning of photoassimilates and cycling of mineral nutrients. J. Exp. Bot. 1996, 47, 1255-1263.

55. Ballicora, M.A.; Iglesias, A.A.; Preiss, J. ADP-Glucose Pyrophosphorylase: A regulatory enzyme for plant starch synthesis. Photosynth. Res. 2004, 79, 1-24.

56. Stitt, M.; Zeeman, S.C. Starch turnover: Pathways, regulation and role in growth. Curr. Opin. Plant Biol. 2012, 15, 282-292.

57. Caspar, T.; Huber, S.C.; Somerville, C. Alterations in growth, photosynthesis, and respiration in a starchless mutant of Arabidopsis thaliana (L.) deficient in chloroplast phosphoglucomutase activity. Plant Physiol. 1985, 79, 11-17.

58. Wang, F.; Sanz, A.; Brenner, M.L.; Smith, A. Sucrose synthase, starch accumulation, and tomato fruit sink strength. Plant Physiol. 1993, 101, 321-327.

59. Muñoz, F.J.; Baroja-Fernández, E.; Morán-Zorzano, M.T.; Viale, A.M.; Etxeberria, E.; Alonso-Casajús, N.; Pozueta-Romero, J. Sucrose synthase controls both intracellular ADP glucose levels and transitory starch biosynthesis in source leaves. Plant Cell Physiol. 2005, 46, 1366-1376.

60. Baroja-Fernández, E.; Muñoz, F.J.; Montero, M.; Etxeberria, E.; Sesma, M.T.; Ovecka, M.; Bahaji, A.; Ezquer, I.; Li, J.; Prat, S.; et al. Enhancing sucrose synthase activity in transgenic potato (Solanum tuberosum L.) tubers results in increased levels of starch, ADPglucose and UDPglucose and total yield. Plant Cell Physiol. 2009, 50, 1651-1662.

61. Barratt, D.H.P.; Derbyshire, P.; Findlay, K.; Pike, M.; Wellner, N.; Lunn, J.; Feil, R.; Simpson, C.; Maule, A.J.; Smith, A.M. Normal growth of Arabidopsis requires cytosolic invertase but not sucrose synthase. Proc. Natl. Acad. Sci. USA 2009, 106, 13124-13129.

62. Cakmak, I.; Kirkby, E.A. Role of magnesium in carbon partitioning and alleviating photooxidative damage. Physiol. Plant 2008, 133, 692-704.

63. Farhat, N.; Ivanov, A.G.; Krol, M.; Rabhi, M.; Smaoui, A.; Abdelly, C.; Hüner, N.P.A. Preferential damaging effects of limited magnesium bioavailability on photosystem I in Sulla carnosa plants. Planta 2015, 241, 1189-1206.

64. Zhang, K.-M.; Yu, H.-J.; Shi, K.; Zhou, Y.-H.; Yu, J.-Q.; Xia, X.-J. Photoprotective roles of anthocyanins in Begonia semperflorens. Plant Sci. 2010, 179, 202-208. 
65. Chou, T.-S.; Chao, Y.-Y.; Huang, W.-D.; Hong, C.-Y.; Kao, C.H. Effect of magnesium deficiency on antioxidant status and cadmium toxicity in rice seedlings. J. Plant Physiol. 2011, 168, 1021-1030.

66. Yang, G.-H.; Yang, L.-T.; Jiang, H.-X.; Li, Y.; Wang, P.; Chen, L.-S. Physiological impacts of magnesium-deficiency in Citrus seedlings: Photosynthesis, antioxidant system and carbohydrates. Trees 2012, 26, 1237-1250.

67. Sobeih, W.Y.; Dodd, I.C.; Bacon, M.A.; Grierson, D.; Davies, W.J. Long-distance signals regulating stomatal conductance and leaf growth in tomato (Lycopersicon esculentum) plants subjected to partial root-zone drying. J. Exp. Bot. 2004, 55, 2353-2363.

68. Wilkinson, S.; Davies, W.J. Drought, ozone, ABA and ethylene: New insights from cell to plant to community. Plant Cell Environ. 2010, 33, 510-525.

69. Timpa, J.D.; Burke, J.J.; Quisenberry, J.E.; Wendt, C.W. Effects of water stress on the organic Acid and carbohydrate compositions of cotton plants. Plant Physiol. 1986, 82, 724-728.

70. Semel, Y.; Schauer, N.; Roessner, U.; Zamir, D.; Fernie, A.R. Metabolite analysis for the comparison of irrigated and non-irrigated field grown tomato of varying genotype. Metabolomics 2007, 3, 289-295.

71. Levi, A.; Paterson, A.H.; Cakmak, I.; Saranga, Y. Metabolite and mineral analyses of cotton near-isogenic lines introgressed with QTLs for productivity and drought-related traits. Physiol. Plant 2011, 141, 265-275.

72. Saito, T.; Matsukura, C.; Ban, Y.; Shoji, K.; Sugiyama, M.; Fukuda, N.; Nishimura, S. Salinity stress affects assimilate metabolism at the gene-expression level during fruit development and improves fruit quality in tomato (Solanum lycopersicum L.). J. Jpn. Soc. Hortic. Sci. 2008, 77, 61-68.

73. Wang, Y.; Ma, F.; Li, M.; Liang, D.; Zou, J. Physiological responses of kiwifruit plants to exogenous ABA under drought conditions. Plant Growth Regul. 2011, 64, 63-74.

74. Munnik, T.; Vermeer, J.E.M. Osmotic stress-induced phosphoinositide and inositol phosphate signalling in plants. Plant Cell Environ. 2010, 33, 655-669.

75. Tewari, R.K.; Kumar, P.; Sharma, P.N. Magnesium deficiency induced oxidative stress and antioxidant responses in mulberry plants. Sci. Hortic. 2006, 108, 7-14.

76. Muchhal, U.S.U.; Pardo, J.M.J.; Raghothama, K.G.K. Phosphate transporters from the higher plant Arabidopsis thaliana. Proc. Natl. Acad. Sci. USA 1996, 93, 10519-10523.

77. Okamoto, M.; Vidmar, J.; Glass, A. Regulation of NRT1 and NRT2 gene families of Arabidopsis thaliana: Responses to nitrate provision. Plant Cell Physiol. 2003, 44, 304-317.

78. Gansel, X.; Muños, S.; Tillard, P.; Gojon, A. Differential regulation of the $\mathrm{NO}_{3}{ }^{-}$and $\mathrm{NH}_{4}{ }^{+}$ transporter genes AtNrt2.1 and AtAmt1.1 in Arabidopsis: Relation with long-distance and local controls by N status of the plant. Plant J. 2001, 26, 143-155.

79. Gierth, M.; Mäser, P.; Schroeder, J.I. The potassium transporter AtHAK5 functions in $\mathrm{K}^{+}$ deprivation-induced high-affinity $\mathrm{K}^{+}$uptake and AKT1 $\mathrm{K}^{+}$channel contribution to $\mathrm{K}^{+}$uptake kinetics in Arabidopsis roots. Plant Physiol. 2005, 137, 1105-1114.

80. Yoshimoto, N.; Takahashi, H.; Smith, F.W.; Yamaya, T.; Saito, K. Two distinct high-affinity sulfate transporters with different inducibilities mediate uptake of sulfate in Arabidopsis roots. Plant J. 2002, 29, 465-473.

81. Connolly, E. Iron stress in plants. Genome Biol. 2002, 3, reviews1024.1-reviews1024.4.

82. Wintz, H.; Fox, T.; Wu, Y.-Y.; Feng, V.; Chen, W.; Chang, H.-S.; Zhu, T.; Vulpe, C. Expression profiles of Arabidopsis thaliana in mineral deficiencies reveal novel transporters involved in metal homeostasis. J. Biol. Chem. 2003, 278, 47644-47653. 
83. Socha, A.L.; Guerinot, M.L. Mn-euvering manganese: The role of transporter gene family members in manganese uptake and mobilization in plants. Front. Plant Sci. 2014, 5, 106, doi:10.3389/fpls.2014.00106.

84. Grotz, N.; Fox, T.; Connolly, E.; Park, W.; Guerinot, M.L.; Eide, D. Identification of a family of zinc transporter genes from Arabidopsis that respond to zinc deficiency. Proc. Natl. Acad. Sci. USA 1998, 95, 7220-7224.

85. Takano, J.; Wada, M.; Ludewig, U.; Schaaf, G.; von Wirén, N.; Fujiwara, T. The Arabidopsis major intrinsic protein NIP5;1 is essential for efficient boron uptake and plant development under boron limitation. Plant Cell 2006, 18, 1498-1509.

86. Snavely, M.D.; Gravina, S.A.; Cheung, T.T.; Miller, C.G.; Maguire, M.E. Magnesium transport in Salmonella typhimurium. Regulation of $m g t A$ and $m g t$ B expression. J. Biol. Chem. 1991, 266, 824-829.

87. Chamnongpol, S.; Groisman, E.A. $\mathrm{Mg}^{2+}$ homeostasis and avoidance of metal toxicity. Mol. Microbiol. 2002, 44, 561-571.

88. Lejona, S.; Aguirre, A.; Cabeza, M.L.; García Véscovi, E.; Soncini, F.C. Molecular characterization of the $\mathrm{Mg}^{2+}$-responsive PhoP-PhoQ regulon in Salmonella enterica. J. Bacteriol. 2003, 185, 6287-6294.

89. Soncini, F.C.; García Véscovi, E.; Solomon, F.; Groisman, E.A. Molecular basis of the magnesium deprivation response in Salmonella typhimurium: Identification of PhoP-regulated genes. J. Bacteriol. 1996, 178, 5092-5099.

90. Mao, D.; Chen, J.; Tian, L.; Liu, Z.; Yang, L.; Tang, R.; Li, J.; Lu, C.; Yang, Y.; Shi, J.; et al. Arabidopsis transporter MGT6 mediates magnesium uptake and is required for growth under magnesium limitation. Plant Cell 2014, 26, 2234-2248.

91. Hattori, M.; Tanaka, Y.; Fukai, S.; Ishitani, R.; Nureki, O. Crystal structure of the ${\mathrm{MgtE} \mathrm{Mg}^{2+}}^{2+}$ transporter. Nature 2007, 448, 1072-1075.

92. Dalmas, O.; Sandtner, W.; Medovoy, D.; Frezza, L.; Bezanilla, F.; Perozo, E. A repulsion mechanism explains magnesium permeation and selectivity in CorA. Proc. Natl. Acad. Sci. USA 2014, 111, 3002-3007.

93. Dalmas, O.; Sompornpisut, P.; Bezanilla, F.; Perozo, E. Molecular mechanism of $\mathrm{Mg}^{2+}$-dependent gating in CorA. Nat. Commun. 2014, 5, doi:10.1038/ncomms4590.

94. Li, Z.; Philip, D.; Neuhaeuser, B.; Schulze, W.X.; Ludewig, U. Protein dynamics in young maize root hairs in response to macro- and micro-nutrient deprivation. J. Proteome Res. 2015, 14, 3362-3371.

95. Kamiya, T.; Yamagami, M.; Hirai, M.Y.; Fujiwara, T. Establishment of an in planta magnesium monitoring system using CAX3 promoter-luciferase in Arabidopsis. J. Exp. Bot. 2012, 63, 355-363.

(C) 2015 by the authors; licensee MDPI, Basel, Switzerland. This article is an open access article distributed under the terms and conditions of the Creative Commons Attribution license (http://creativecommons.org/licenses/by/4.0/). 